Human

Development

\title{
Opinions about contraception and sexual behavior in southern Brazil's college youth
}

\author{
André T. Stephanou ${ }^{1}$ \\ iD https://orcid.org/0000-0003-1135-5870 \\ Marina Z. Delatorre ${ }^{1}$ \\ https://orcid.org/0000-0002-8475-6213 \\ Ana Cristina G. Dias ${ }^{1}$ \\ https://orcid.org/00oo-0003-2312-3911
}

How to cite this article: Stephanou, A. T., Delatorre, M. Z., \& Dias, A. C. G. (2020). Opinions about contraception and sexual behavior in southern Brazil's college youth. Psicologia: Teoria e Prática, 22(3), 115-136. doi:10.5935/1980-6906/psicologia.v22n3p115-136

Submission: $07 / 27 / 2018$

Acceptance: 06/23/2020

(cc) BY

The content of Psicologia: Teoria e Prática is distributed under the terms of the Creative Commons Attribution License.

1 Federal University of Rio Grande do Sul (UFRGS), Porto Alegre, RS, Brazil. 


\begin{abstract}
The transition to university is a delicate moment in development, in which individuals may be exposed to many stressors and also exhibit risky behaviors, such as unprotected sex. This study aimed to analyze differences in opinions about contraception based on self-reported sexual and contraceptive behavior. Around 253 sexually active young students answered a questionnaire on sociodemographic and sexual behavior data and a scale on contraceptive opinions. The use of contraceptives was reported by $95 \%$ of participants, but only $22 \%$ claimed consistent condom use. Inconsistent condom use was associated with negative opinions regarding its impact on sexual intercourse. Amongst women, condom use was associated with opinions of higher assertiveness in the negotiation of contraceptive methods. Men were less favorable of the idea of discussing contraceptive methods as a couple. Contraception support interventions must take into account the different barriers that affect men's and women's contraceptive behaviors.
\end{abstract}

Keywords: sexual behavior; contraception; youth; pregnancy; college students.

\title{
OPINIÕES SOBRE CONTRACEPÇÃO E COMPORTAMENTO SEXUAL EM JOVENS UNIVERSITÁRIOS DO SUL BRASILEIRO
}

\section{Resumo}

A transição para a universidade é um momento sensível do desenvolvimento no qual os indivíduos podem estar expostos a mais estressores e exibir comportamentos de risco, como sexo desprotegido. Este estudo teve como objetivo investigar diferenças em opiniões sobre contracepção com base no comportamento sexual autorrelatado. Jovens estudantes sexualmente ativos (253) responderam a um questionário sobre dados sociodemográficos e comportamento sexual, e a uma escala de opiniões sobre contracepção. O uso de contraceptivos foi reportado por $95 \%$ dos participantes, mas apenas $22 \%$ relataram uso consistente de camisinha. Uso inconsistente de camisinha esteve associado a opiniões negativas sobre seu impacto na relação sexual. Entre as mulheres, o uso de camisinha se associou a opiniões de maior assertividade na negociação de métodos contraceptivos. Homens se mostraram menos favoráveis a discutir métodos contraceptivos em casal. Intervenções de suporte à contracepção devem levar em conta as diferentes barreiras à contracepção que afetam homens e mulheres.

Palavras-chave: comportamento sexual; contracepção; jovens; gravidez; universitários. 


\title{
OPINIONES SOBRE ANTICONCEPCIÓN Y CONDUCTA SEXUAL DE JÓVENES UNIVERSITARIOS DEL SUR DE BRASIL
}

\begin{abstract}
Resumen
La transición a la universidad es un momento sensible en el desarrollo en que las personas pueden estar expuestas más factores estresantes y también exhiben conductas arriesgadas, como el sexo sin protección. Este estudio tuvo como objetivo verificar diferencias de opiniones sobre anticoncepción y la conducta sexual autoinformada. 253 jóvenes estudiantes sexualmente activos llenaron un cuestionario de dados sociodemográficos y conducta sexual y una escala sobre opiniones contraceptivas. El uso de contraceptivos fue reportado por 95\% de los participantes, pero solo $22 \%$ relataran uso del condón. El impacto del condón en el sexo fue asociado con sexo desprotegido. Entre las mujeres, el uso del condón fue asociado con opiniones de mayor asertividad en la negociación de métodos contraceptivos. Hombres fueron menos favorables de la idea de discutir métodos contraceptivos como pareja. Intervenciones de soporte a la contracepción deben considerar las diferentes barreras que afectan las conductas de hombres y mujeres.

Palabras-clave: conducta sexual; contracepción; jóvenes; embarazo; universitarios.
\end{abstract}

\section{Introduction}

The transition to higher education may be one of the first relevant experiences of autonomy for young Brazilian students (Monteiro, Tavares, \& Pereira, 2009; Santos, Seidl-de-Moura, Victor, \& Ramos, 2016). This period is different from adolescence and adulthood because young people become more independent from their parents and experience different possibilities in their affective and professional lives, while not yet taking on typical adult commitments (Monteiro et al., 2009).

The less surveilled environment may favor the occurrence of risky health behaviors. A study with 352 first-year university students from a public university in the state of Paraná reported that approximately $40 \%$ of the sample increased their alcohol consumption after starting university education (Carvalho, Pereira, Reus, \& Limberger, 2014). Furthermore, findings from a survey with 550 university students from the south of Brazil suggest that risk behavior performance is more frequent among senior students when compared to their first-year counterparts 
(Campos, Isensse, Rucker, \& Bottan, 2016). Although risky sexual behaviors are associated with lower age and fewer years of formal education, and that college students use contraceptive methods more frequently than the average population of the same age (Hugo et al., 2011), they also perform unprotected sex regularly. Approximately $60 \%$ of university students report not using condoms in the last instance of sexual intercourse (Borges, Silveira, Santos, \& Lippi, 2015; Moreira, Dumith, \& Paludo, 2018). When considering condom use frequency in the past, about a third of students reported always using condoms (Alves, Gonçalves, Fontoura, \& Neves, 2017; Campos et al, 2016; Silva, Camargo, \& Iwamoto, 2014), with some studies reporting rates as low as 20\% (Borges et al., 2015). Therefore, studies must investigate which factors related to sexual behavior may increase the risk of sexually transmitted infections (STIs) and unintended pregnancies in college students.

The recent increase in the incidence of HIV and other STIs in the young population of Brazil underscores the importance of research about the sexual behavior of this population (Ministério da Saúde, 2017). However, studies in Brazil and abroad show that young people are more concerned about avoiding unintended pregnancies than preventing STIs (Borges et al., 2015; Brown, 2015; Quintana, Calatayud, \& Lanterna, 2016). The greater concern with pregnancy, to the detriment of STIs prevention, was also demonstrated by the reports that, as relationships grow stable, young people tend to abandon condom use in favor of hormonal contraceptives (Alves et al., 2017; Janeiro, Oliveira, Rodrigues, Maceiras, \& Rocha, 2013).

In this scenario, there is an asymmetry between men and women regarding the responsibility of contraceptive planning (Brown, 2015; Fennel, 2011), as the use of hormonal contraceptives is exclusive to the female population. This asymmetry is also present in occasional sexual encounters, ever more common amongst the young population (Chaves, 2016). Moreover, cultural factors influence the construction of socially performed gender roles, affecting how individuals of each sex behave (Heilborn \& Cabral, 2013; James-Hawkins, Dalessandro, \& Sennot, 2019).

Research on adolescents and young people's contraception highlights the different roles attributed to men and women in this process. A qualitative study with young couples in the United States describes this division of roles being present even before the first sexual experience (Fennel, 2011). While girls are taught about hormonal contraception, boys get condoms as the only contraceptive strategy. 
Notwithstanding, Fennel (2011) found that women were more knowledgeable about condoms than regarding hormonal contraceptives, stressing the larger burden placed on women in matters of reproductive health. Furthermore, research suggests that women present more positive attitudes and intentions to condom use when compared to men (Brown, 2015; Janeiro et al., 2013; Rich, Mullan, Sainsbury, \& Kuczmierczyk, 2014). Hence, women are more often held responsible for contraceptive use, whether oral contraceptives in long-term relationships or the use of condoms in occasional encounters (Brown, 2015).

This study aimed to investigate differences in self-reported sexual and contraceptive behavior of young college students. It was expected that, as reported in the literature, there would be differences in student's contraceptive behavior according to their opinions about contraceptive methods. Similarly, it was anticipated that opinions on contraception would differ between men and women, and between those with and without a stable partner.

\section{Method}

\subsection{Participants}

Participants for this study were selected from a convenience sample of students from public and private undergraduate programs in Business Administration, Accounting, Law, and Psychology, from a city in the state of Rio Grande do Sul. Individuals that were not sexually active or those that did not report sexual intercourse with people from the opposite sex were excluded from the sample. The final sample included 253 university students.

\subsection{Measures}

A questionnaire about sociodemographic data and contraceptive behavior was used for data collection, as well as a scale on opinions about contraception. The questionnaire on contraceptive behavior requested information about age at sexual debut, the existence of a current stable sexual partner, which contraceptive methods were used in the first sexual intercourse, as well as in the past year, and the latest sexual intercourse. Participants were asked whether or not they had a stable partner in the last year, and how many casual partners they had. Participants were asked if they had used any contraceptive methods in their first sexual 
intercourse and in the past year, with a yes/no response option. Condom use was further investigated with questions about condom use in the first sexual intercourse, in the latest sexual intercourse, and about the frequency of condom use in the past year. The frequency of condom use was measured with four levels: "never"; "a few times"; "often, but not always"; "always." Responses were collapsed into two categories for analysis, "consistent" ("always" option) and "inconsistent" (all other options).

The scale on opinions about contraception was developed by the researchers based on a literature review on the topic and remarks collected from interviews conducted with pregnant teenagers. A first version of the scale was discussed with a group of Psychology students to ensure the clarity of items to the college population. The suggestions offered by these students were incorporated into the version used in this study. Participants were instructed to indicate, on a scale from 1 to 7 , how much they disagreed with each statement, 1 being "completely agree," and 7, "completely disagree." The scale used for data collection was composed of 24 items, assessing aspects of contraceptive methods negotiation, the perceived difference in responsibility between genders, and the impact of condom use in sexual intercourse. Although all items refer to contraceptive methods and behavior, they were analyzed individually, as the meaning of a total score is not clearly interpretable.

\subsection{Procedures}

Participants answered both measures in their classrooms during a time slot granted by the professors, following a presentation of the research and signature of the consent form. No student declined to participate. Data were manually inserted in an electronic database and analyzed with SPSS v. 18 software.

Data were analyzed with descriptive statistics regarding the characterization of the sample. The Shapiro-Wilk test was used to evaluate the normality of variable distributions. Due to the non-normal distribution of the item responses for the contraceptive opinion scale, Mann-Whitney $U$ tests were conducted to assess the difference in opinions about contraceptive practices between genders, as well as between people that reported using contraceptives in the past year, between people with and without stable partners, and between people with frequent and infrequent condom use behavior. Effect sizes ( $r$ ) were calculated by dividing the standardized test statistic by the square root of the sample size. Chi-square tests were used to 
analyze gender differences in contraceptive use, condom use frequency, and other sexual behavior categorical data. The alpha level was set to 0.05 for all analyses.

The research abided by the ethical guidelines stated in the Resolution No. 196/96 of the Ministério da Saúde (Ministry of Health). The project was evaluated and approved by the Research Ethics Committee of the Federal University of Santa Maria, Presentation Certificate for Ethical Appreciation (Certificado de Apresentação para Apreciação Ética [CAAE]) No. 03958712.0.0000.5346.

\section{Results}

The mean age of participants was $21.2(S D=1.8)$. Approximately $58 \%$ of the sample was comprised of women. Participants self-identified as white were $91 \%$, as pardo (from the Brazilian Portuguese, meaning a black and white mixed-race), $6 \%$, as black, $2 \%$, and as Asian $1 \%$. The monthly mean family income was 8.5 minimum wages $(S D=7.8)$, varying from 0.9 up to 48.2 minimum wages.

The mean age for the first instance of sexual intercourse in the sample was 16.2 (SD $=1.88)$. Most of the sample $(66 \%)$ reported having their first sexual encounter with a stable partner. Eighty-seven percent of participants reported using some method of contraception in their first sexual intercourse, while, for the past year, $94.8 \%$ of the sample reported the use of contraceptives. As for condom use, $82.6 \%$ of the sample reported using them in their first sexual intercourse, as opposed to $65.2 \%$ in the last instance of sexual intercourse. Regarding the past year, only $21.7 \%$ of participants reported always using condoms.

Women reported older age (16.6) at the first instance of sexual intercourse when compared to men (15.7), $U=5.295, p<.001, r=-0.26$. Age at first sexual intercourse was higher for participants that reported consistent condom use in the previous year, $U=3.475, p=.001, r=-0.22$. A similar difference was found for the use of contraceptives, both in the first sexual intercourse, $U=2.483$; $p=.015, r=$ -0.15 , and in the previous year, $U=857, p=.007, r=-0.17$. Women had their first sexual intercourse with their boyfriends in $84 \%$ of cases, while only $42 \%$ of men reported having their sexual initiation with their girlfriends, $\chi^{2}(1, n=253)=$ 47.41, $p<.001$.

Women reported more frequent use of contraceptives than men, both in the first sexual intercourse $(92.5 \%$ vs. $81.3 \%), \chi^{2}(1, n=253)=7.15, p=.007$, and in the previous year $(97.9 \%$ vs. $90.6 \%), \chi^{2}(1, n=253)=6.84, p=.020$. Condom use 
in the first sexual intercourse was similar between genders, $85.6 \%$ of cases for women and $78.5 \%$ for men, $\chi^{2}(1, n=253)=2.17, p=.140$. Regarding the frequency of condom use in the previous year, men reported higher rates of consistent condom use, $\chi^{2}(1, n=253)=4.32, p=.038$, with $28 \%$ of men reporting having used condoms in every sexual encounter, compared to $17.1 \%$ of women.

When questioned about the current relationship status, more women (87\%) than men $(52 \%)$ reported having a stable partner in the previous year, $\chi^{2}(1, n=$ $251)=36.7, p<.001$. Amongst all participants that reported having a stable partner, $93.8 \%$ stated that they talked with their partners about contraception, compared to $68.3 \%$ of those without stable partners, $\chi^{2}(1, n=243)=27.24, p<.001$.

Mann-Whitney tests were used to analyze the answers to the scale of opinions on contraception, in order to identify differences between genders. Women in the sample were more opposed to the idea that men should have more power in contraceptive decisions, $U=10.807, p<.001, r=0.37$. They also agreed more with the statement that women should always carry condoms with them, $U=6.181, p=$ .031, $r=-0.14$, and felt more comfortable with the discussion of contraceptive strategies with their partners, $U=6.544, p=.008, r=-0.17$. Women were less likely to believe that condom use affects aspects such as sexual desire, $U=9.225$, $p=.007, r=0.17$, and sexual performance, $U=9.019, p=.002, r=0.19$. They were also less disposed to give up on using condoms if the partner was not willing to use them, $U=9.744, p=.001, r=0.22$. Conversely, women appeared less likely to agree to use a condom by their partner's request, $U=9.617, p<.001, r=0.22$, if they were initially unwilling to do so.

Despite usually agreeing with the items referring to joint decision making, men disagreed significantly more than women about the need for the couple to discuss contraceptive choices, $U=6.709, p=.014, r=-0,16$, and were less supportive of the idea that a man should be concerned about contraception if the woman uses any contraceptive method, $U=5.854, p<.001, r=0.23$. As for condom use, men seemed to care less about the idea of sexual intercourse without a condom than women, agreeing more that trust in the partner allows for being less concerned about contraception use, $U=10.138, p<.001, r=0.27$. Men disagreed more with the statement that they would refuse sex with a partner unwilling to use condoms, $U=5.448, p<.001, r=-0.27$. They also agreed less with the idea of trying to convince an unwilling partner to use condoms, $U=6.228, p=.005, r=-0.18$. Men 
agreed more with the statement that they had "more composure to remember to use condoms during sexual intercourse," $U=10.288, p<.001, r=0.28$. Likewise, women agreed more with the statement that they "have more of a 'clear head' during sexual intercourse," $U=6.127, p=.003, r=-0.19$. It is important to note that participants were overall supportive of the notion that women are more suited to remember to use a condom during intercourse, while they mostly disagreed in regards to men's ability to do so. A summary of the mean responses to the items of the scale, by gender, can be seen in Table 3.1. 
Table 3.1. Mean responses to items on opinions about contraception by gender and total sample.

\begin{tabular}{|c|c|c|c|c|}
\hline Item & $\begin{array}{c}\text { Total } \\
n=253\end{array}$ & $\begin{array}{c}\text { Men } \\
n=107\end{array}$ & $\begin{array}{l}\text { Women } \\
n=146\end{array}$ & $p^{*}$ \\
\hline $\begin{array}{l}\text { 1. The man must decide about the couple's contraceptive } \\
\text { method. }\end{array}$ & 5.85 & 5.14 & 6.36 & .001 \\
\hline $\begin{array}{l}\text { 2. The manner in which a couple prevents an unintended } \\
\text { pregnancy must be decided jointly. }\end{array}$ & 1.61 & 1.93 & 1.38 & .157 \\
\hline 3. The responsibility of contraception is with the woman. & 5.45 & 5.33 & 5.55 & .316 \\
\hline 4. Men must always carry condoms with them. & 2.30 & 2.45 & 2.18 & .560 \\
\hline 5. Women must always carry condoms with them. & 3.05 & 3.41 & 2.78 & .031 \\
\hline $\begin{array}{l}\text { 6. The man must support the financial cost of the } \\
\text { contraceptive methods used by the couple. }\end{array}$ & 4.96 & 4.68 & 5.16 & .068 \\
\hline $\begin{array}{l}\text { 7. The couple must split the cost of condoms and other } \\
\text { contraceptive methods. }\end{array}$ & 2.99 & 2.95 & 3.01 & .560 \\
\hline $\begin{array}{l}\text { 8. I feel comfortable discussing contraceptive use with my } \\
\text { partner. }\end{array}$ & 1.78 & 2.11 & 1.53 & .008 \\
\hline $\begin{array}{l}\text { 9. It's hard to talk about contraceptive use with a one- } \\
\text { night stand. }\end{array}$ & 3.91 & 3.69 & 4.08 & .284 \\
\hline $\begin{array}{l}\text { 10. The couple must feel comfortable discussing } \\
\text { contraceptive use. }\end{array}$ & 1.54 & 1.92 & 1.27 & .014 \\
\hline 11. Condom use affects sexual desire. & 4.30 & 3.88 & 4.61 & .007 \\
\hline 12. Condom use affects sexual performance. & 4.96 & 4.49 & 5.30 & .002 \\
\hline $\begin{array}{l}\text { 13. In "the heat of the moment", the woman manages } \\
\text { to have more of a "clear head" to remember to use a } \\
\text { condom. }\end{array}$ & 3.43 & 3.92 & 3.08 & .003 \\
\hline $\begin{array}{l}\text { 14. The man has more composure to remember to use a } \\
\text { condom during sex. }\end{array}$ & 5.14 & 4.64 & 5.51 & .001 \\
\hline 15. Preventing a pregnancy should be a female concern. & 5.27 & 5.38 & 5.19 & .456 \\
\hline $\begin{array}{l}\text { 16. If the woman uses any contraceptive, the man must } \\
\text { not be concerned about it. }\end{array}$ & 5.72 & 5.25 & 6.06 & .001 \\
\hline $\begin{array}{l}\text { 17. When the woman uses the pill, the man must be } \\
\text { concerned about how she does it. }\end{array}$ & 2.23 & 2.53 & 2.00 & .019 \\
\hline $\begin{array}{l}\text { 18. The man must always be concerned about the use of } \\
\text { contraceptive methods in sexual intercourse. }\end{array}$ & 1.90 & 2.28 & 1.62 & .006 \\
\hline $\begin{array}{l}\text { 19. When there is sexual intercourse, the woman is the } \\
\text { one who should be concerned about contraception. }\end{array}$ & 5.56 & 5.47 & 5.62 & .430 \\
\hline $\begin{array}{l}\text { 20. If I trust my partner, I accept that he/she takes } \\
\text { responsibility for contraception. }\end{array}$ & 4.79 & 4.16 & 5.25 & .001 \\
\hline $\begin{array}{l}\text { 21. I'd refuse to have sex with a partner that would not } \\
\text { use a condom. }\end{array}$ & 2.96 & 3.60 & 2.49 & .001 \\
\hline $\begin{array}{l}\text { 22. I'd rather use a condom, but I wouldn't mind having } \\
\text { sex if my partner didn't want to use one. }\end{array}$ & 4.97 & 4.50 & 5.32 & .001 \\
\hline $\begin{array}{l}\text { 23. I don't like using condoms, but if my partner insists, I } \\
\text { agree to use it. }\end{array}$ & 4.11 & 3.49 & 4.56 & .001 \\
\hline $\begin{array}{l}\text { 24. When I am with a partner that doesn't want to use a } \\
\text { condom, I try to talk and reach an agreement. }\end{array}$ & 2.27 & 2.57 & 2.06 & .005 \\
\hline
\end{tabular}

Note: *Mann-Whitney $\mathrm{U}$ test was used to assess the difference between genders. $1=$ completely agree and $7=\mathrm{com}-$ pletely disagree. 
Table 3.2 displays results comparing participants that used contraceptives in the past year to those that did not. Participants who reported the use of contraceptives in the previous year were more likely to disagree that contraception is the responsibility of the woman, $U=2.154, p=.007, r=0.17$. They also disagreed that the man must decide about contraception for the couple, $U=2.200, p=.004$, $r=0.18$. Such participants also agreed more that they would refuse sex with a partner that was unwilling to use condoms, $U=1.017, p=.029, r=-0.14$. Analyzing by gender, men that did not use contraceptives in the previous year showed more opposition to the idea that condom use affects sexual desire, $U=275, p=.024, r=$ -0.22 . Only three women reported not using contraceptives in the previous year. They were more likely to agree with statements that the woman must be responsible for contraception, $U=74, p=.038, r=0.17$. 
Table 3.2. Mann-Whitney $\mathrm{U}$ tests for the difference in opinions about contraception and contraceptive use in the past year, by gender and total sample.

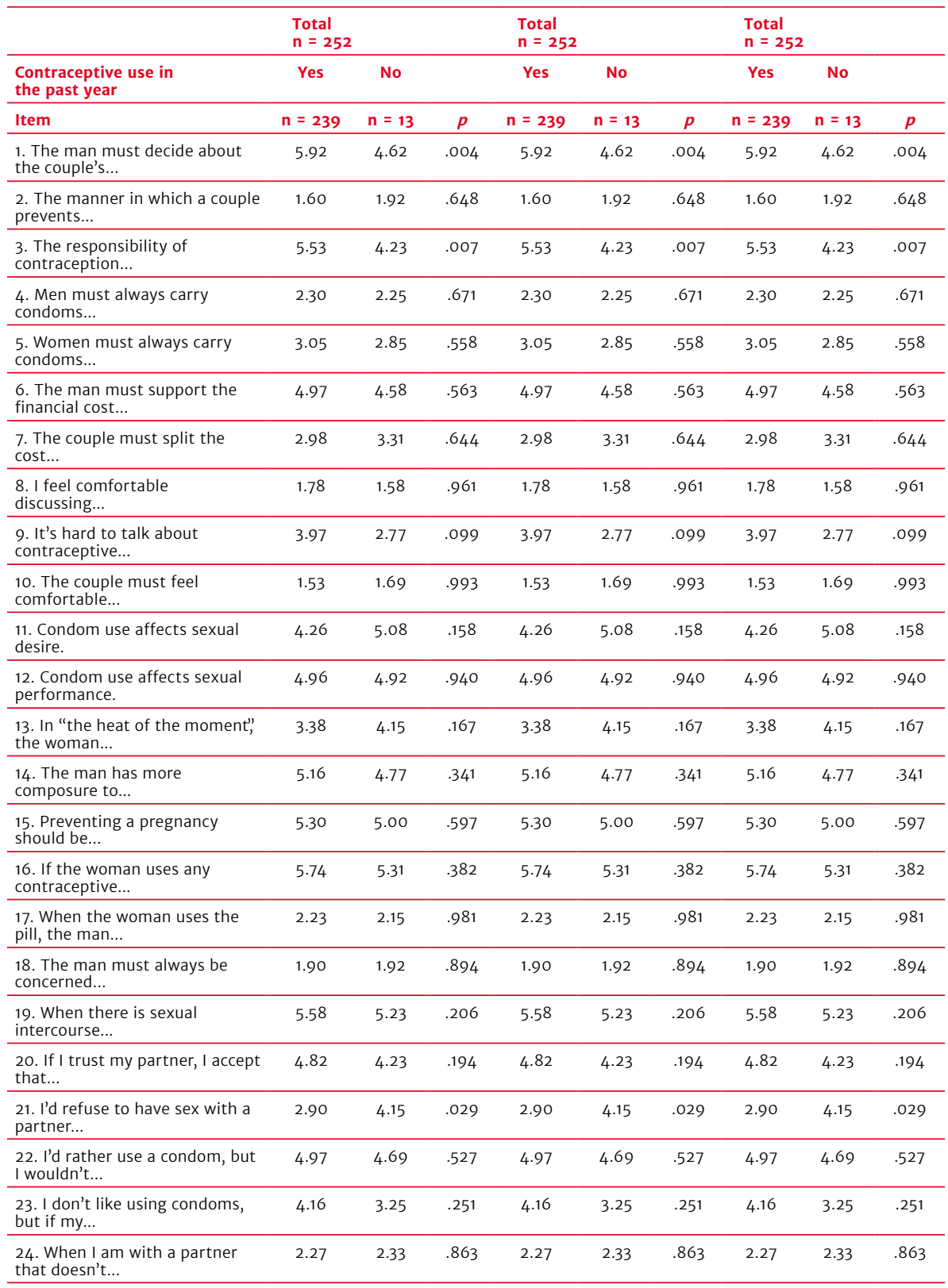

Note: $1=$ completely agree and 7 = completely disagree 
Table 3.3 shows the means and the results of the Mann-Whitney tests comparing participants that reported having always used condoms in the past year with those that did not. The group that reported inconsistent condom use showed more support for the statements that they would accept the choice of their partner, whether it is using a condom, $U=6.741, p=.002, r=0.19$, or not, $U=7.023, p=$ $.001, r=0.21$. The idea that condom use affects sexual desire was more accepted by participants that reported inconsistent condom use, $U=6.281, p=.039, r=0.13$. Participants that reported always using condoms were more supportive of the notion that men must always carry condoms with them, $U=4.122, p=.010, r=$ -0.16 , and that the couple should split the cost of contraception, $U=4.143, p=$ $.007, r=-0.17$. They also endorsed the idea that it is easier for men to remember to use a condom during an encounter, $U=4.353, p=.020, r=-0.15$. 
Table 3.3. Mann-Whitney $\mathrm{U}$ tests for the difference in opinions about contraception and condom use frequency in the past year, by gender and total sample.

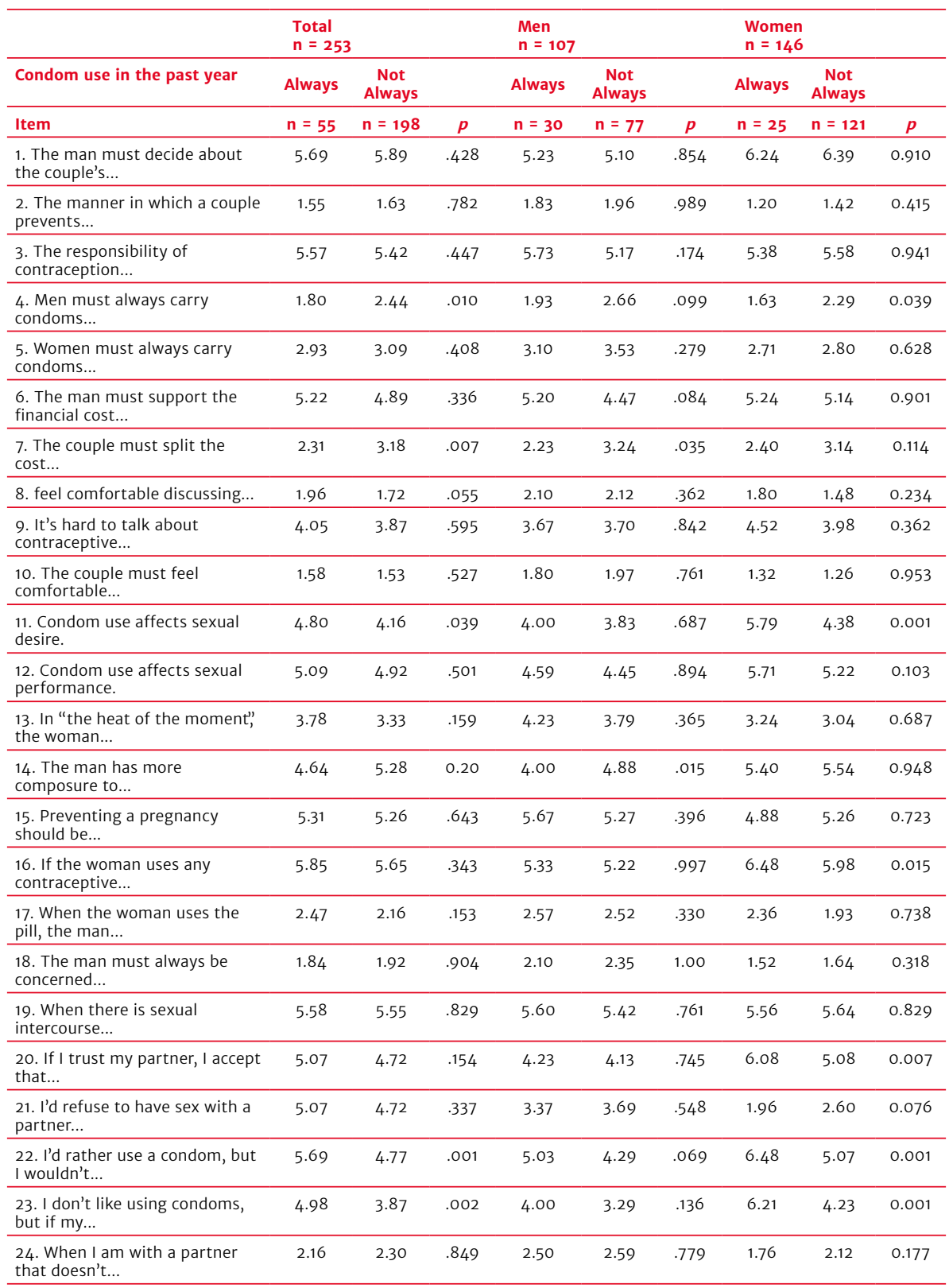

Note: $1=$ completely agree and 7 = completely disagree 
Women who reported inconsistent condom use valued trust in a partner more highly as a factor to take into account during the contraceptive decision making process, $U=2.012, p=.007, r=0.22$, although both groups of women disagree more with this statement than men did. Women that reported always using condoms in the past year disagreed more that man can be exempt from the contraceptive process in case the woman is taking some measure of birth control, $U=1.926, p=.015, r=0.20$. The group with inconsistent condom use behavior showed more opposition to the statement that men should always carry condoms with them, $U=1.077, p=.038, r=-0.17$. Likewise, the statement that using condoms affects sexual desire was endorsed more by women that reported inconsistent condom use, $U=2.076, p=.001, r=0.29$. In line with the analysis of the entire sample, women that reported consistent condom use were less likely to endorse opinions about accepting a partner's proposal that went against their choice of condom use, $U=2.218, p<.001, r=0.32$, for not using a condom despite wanting to, and $U=2.165, p<.001, r=0.32$, for using a condom despite not wanting to.

Men that reported inconsistent condom use in the past year disapproved of the idea that couples should split contraceptive costs, $U=842, p=.035, r=-0.21$. On the other hand, men that reported always using condoms agreed more that men have an easier time remembering to use condoms during sexual intercourse, $U=809, p=.014, r=-0.24$.

Participants that reported having a stable partner were different from those that did not in several items of the scale. People in relationships agreed more with assertions that a couple should feel comfortable discussing contraception, $U=5.448, p=.026, r=-0.14$, that they felt comfortable themselves in doing so, $U=4.827, p=.001, r=-0.21$, and that they would attempt to negotiate condom use with an unwilling partner, $U=4.992, p=.009, r=-0.17$. They were more likely to believe that they would refuse unprotected sex with a partner unwilling to use a condom, $U=4.142, p<.001, r=-0.27$, and less likely to agree they would agree to have unprotected sex despite wanting to use condoms, $U=7.347, p=.033, r=0.13$. Participants in stable relationships also agreed more with the idea of women having an easier time remembering to use a condom during intercourse, $U=5.024$, $p=.013, r=-0.16$, and disagreed that men should decide about the couple's contraceptive method, $U=7.298, p=.024, r=0.14$. Data concerning these items are described in Table 3.4 . 
Table 3.4. Mann-Whitney $\mathrm{U}$ tests for the difference in opinions about contraception and partner type in the past year by gender and total sample

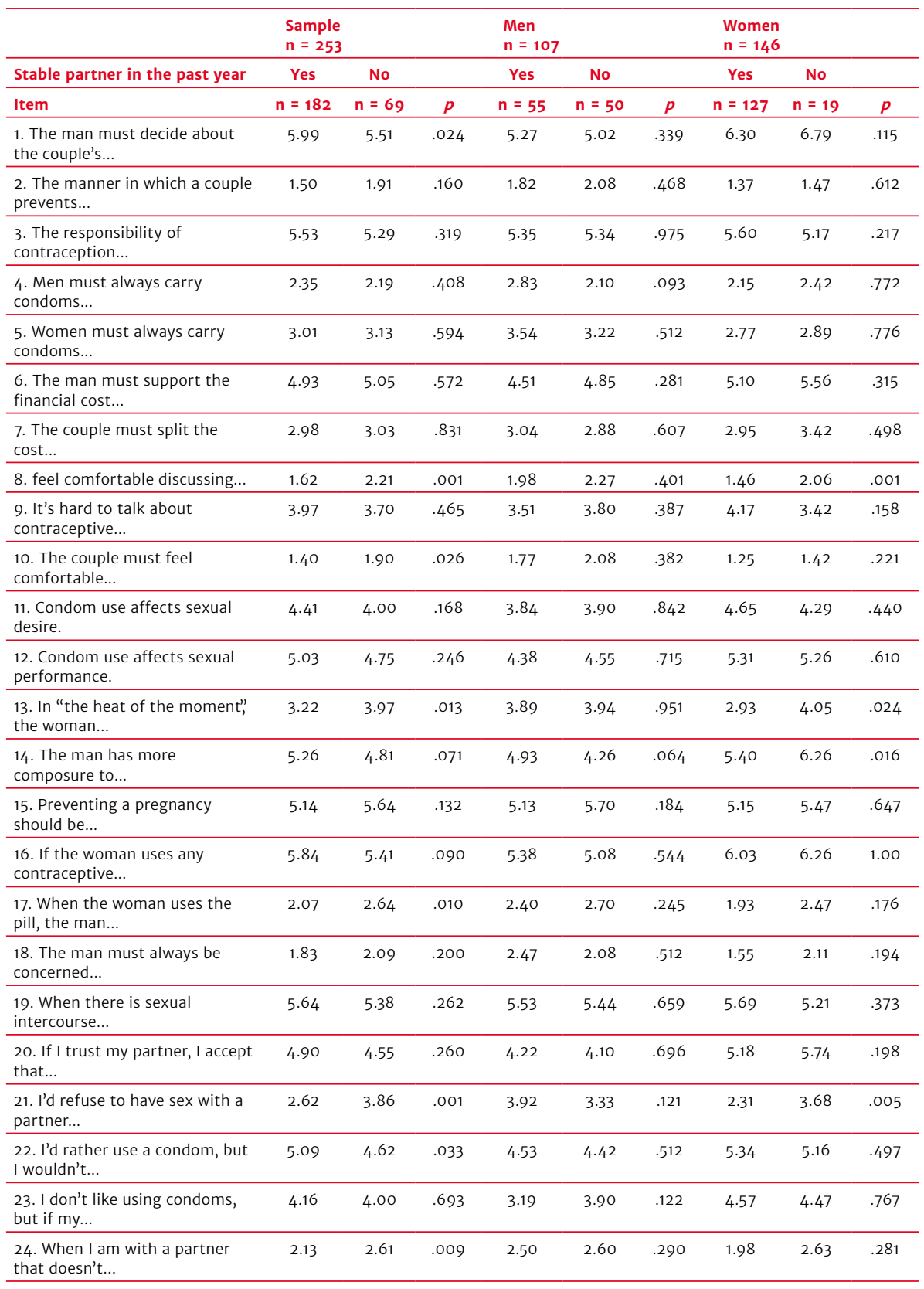

Note: $1=$ completely agree and $7=$ completely disagree. 
There were no significant differences in opinions about contraception and partner type amongst men in the sample. As for women, those without stable partners disagreed more about men's ability to remember to use a condom during sexual intercourse, $U=805, p=.015, r=-0.20$. Women without stable partners also disagreed more with the statement that women have more of a "clear head" during sexual intercourse, $U=829, p=.024, r=-0.19$. Women without stable partners also showed less disposition to deny unprotected sex, $U=760, p=.005$, $r=0.23$, if that was their partner's desire.

\section{Discussion}

The age of first sexual intercourse found in this study is close to those reported in other studies with college students (Gomes \& Nunes, 2015; Moreira et al., 2018; Silva et al., 2014). The difference between genders, with college-aged women reporting later sexual initiation, has also been reported elsewhere (Alves et al., 2017; Quintana et al., 2016). Other studies with college students observed that those with earlier sexual initiations were more likely to report inconsistent condom use (Gomes \& Nunes, 2015; Moreira et al., 2018). These findings corroborate the observations that participants in this study that had their first sexual intercourse later were more likely to report consistent condom use in the previous year. They were also more likely to report the use of contraceptives both in the first sexual intercourse, as well as in the current ones. In the present study, there was no difference in age at first sexual intercourse based on condom use at that moment. A longitudinal study investigating the sexual behaviors of American young adults found that the connection between early sexual initiation and subsequent sexual risk-taking behaviors may be mediated by executive function, such as low selfcontrol (Magnusson, Crandall, \& Evans, 2019). This could be one explanation for the results found in the present study, although new research is needed to test this hypothesis.

Condom use in the first sexual intercourse did not differ between genders. However, regarding condom use in the previous year, men reported higher rates than women, consistent with results found by Moreira et al. (2018). Nevertheless, a sizeable difference was observed between the reports of condom use in the first sexual intercourse and the previous year, with a general decrease in condom use. This difference was already reported by other authors (Janeiro et al., 2013; Quintana 
et al., 2016), who attribute it to the higher proportion of stable relationships among older college students. Ideas about trust in the partner, the assumption of monogamy in the relationship and the importance placed on the spontaneity of sexual intercourse between partners would be linked to the decrease of condom use in favor of hormonal methods in stable relationships (Moreira et al., 2018; Quintana et al. 2016; Silva et al., 2014).

As discussed in the literature (Moreira et al., 2018), it was agreed that trust in the partner as an important aspect of contraceptive planning was more salient for women that reported inconsistent use of condoms, but not for men. Considering the sample as a whole, women disagreed more strongly with the statement that trust is a reason for accepting the partner taking responsibility for contraception. These results reinforce the idea that women consider themselves as more accountable for contraception than men. Even the ones that were more willing to give up responsibility if they trusted the partner, and did so by using condoms less frequently, ended up using other methods exclusive for females, such as the hormonal pill or the IUD. This scenario reflects the dilemma described by James-Hawkins et al. (2019) regarding balancing responsibility for contraception and women's bodily autonomy, which reinforces the women's burden regarding contraception and pregnancy, even when trying to prevent inequality.

It is important to note that participants with stable partners disagreed more than the ones without stable partners that the man should decide about the couple's contraceptive method, suggesting that stable relationships may bring some gender balance about contraception responsibilities. In addition, women without stable partners were less favorable to the opinion that men have more composure to remember to use a condom during sexual intercourse. Thus, for these women, condoms are unlikely to be used if the couple does not plan to do so.

Participants in stable relationships were less likely to refuse unprotected sex, in case the partner was not willing to use a condom. Amongst women, those without a stable partner were less likely to decline sex with a partner that refused to use a condom. This apparent lack of assertiveness to negotiate, observed in the single women of the sample, demonstrates the asymmetry of the decision process regarding the use of contraceptives. Heilborn and Cabral (2013) state that even with the modernization of attitudes about sexual practices that are considered acceptable, gender stereotypes still influence young people's sexual behavior, 
across multiple social strata. Interview data from twelve youth aged between 18 and 25 years old describe that young men felt more comfortable with the uncertainty of casual encounters, while women showed more concern about engaging in stable relationships (Chaves, 2016).

Among the items that presented differences in opinions by gender, women appeared to have more willingness to discuss the decision-making process regarding contraceptive methods, including a less negative perception of the impact of condom use in sexual intercourse. Men showed less proclivity for talking about contraception, which is coherent with the findings of Fennel (2011) that reports that men are not socialized to think about contraceptive methods other than the condom. They also frequently assume that their partners are already taking some form of contraception, as reported in other studies with young people (Brown, 2015).

Men in the sample showed more agreement with statements about the impact of the condom on sexual performance, particularly sexual desire. This suggests that even though men are more socialized to this method (Fennel, 2011), they seem to have more negative opinions about it when compared to women. Rich et al. (2014) also describe this negative evaluation of the impact of condoms amongst men in a study with British teenagers.

However, the present results suggest that men's opinions about the impact of condom use on sexual intercourse do not differ based on self-reported condom use behavior. This suggests the need to explore other factors that may influence condom use. Men that reported inconsistent condom use had more negative opinions about: 1 . the idea of splitting contraception costs with the partner, and 2 . the fact that men had more composure during sexual intercourse to remember to use a condom.

This study had a few limitations. First, the sample of college students does not allow for the data to be generalized for young people of lower educational levels, which are affected by different cultural norms (Heilborn \& Cabral, 2013). Furthermore, given the cross-sectional study design, it is not possible to analyze the causes of the differences between groups. Moreover, the lack of a clear psychometric structure to the scale restricted the analysis to individual item responses. It is also possible that the scale used is more representative of the female experience, taking into consideration that it was partially informed by a focus group consisting only of young women. However, it is possible to present an 
overview of the opinions on contraception of college students, providing suggestions of aspects to be considered in interventions aimed at contraceptive behaviors with this population.

In general, the results show that there are difficulties with joint decisionmaking and negotiation over the use of contraceptives. Participants that reported inconsistent use of contraceptives, particularly condoms, were more likely to endorse opinions against contraceptive planning. Differences in opinion on contraception between men and women in the present sample corroborate the need for interventions that consider the peculiarity of each gender, including relational and gender roles aspects, concerning contraceptive behavior. Additionally, there is also the need for these interventions to emphasize the role of condoms as the only method available to prevent both STIs and pregnancies, given the tendency of young people to forego condom use gradually after sexual initiation and/or the start of a stable relationship. More research is necessary to explore other factors associated with contraceptive use, besides those investigated in this study.

\section{References}

Alves, B., Gonçalves, M. B., Fontoura, L. V., \& Neves, G. D. (2017). Perfil sexual de estudantes universitários. Revista Brasileira em Promoção da Saúde, 30(4), 1-8. doi:10.5020/18061230.2017.6219

Borges, M. R., Silveira, R. E. D., Santos, Á. D. S., \& Lippi, U. G. (2015). Sexual behaviour among initial academic students. Revista Online de Pesquisa: Cuidado é Fundamental, 7(2), 2505-2515. doi: 10.9789/2175-5361.rpcfo.v7.3676

Brown, S. (2015). "They think it's all up to the girls": Gender, risk and responsibility for contraception. Culture, Health \& Sexuality, 17(3), 312-325. doi:10.1080/13691058. 2014.950983

Campos, L. L., Isensse, D. C., Rucker, T. C., \& Bottan, E. R. (2016). Condutas de saúde de universitários ingressantes e concluintes de cursos da área da saúde. Revista Brasileira de Pesquisa em Saúde, 18(2), 17-25. doi:10.21722/rbps.v18i2.15080

Carvalho, M. A. V., Corrêa, M. P., Reus, T. L., \& Limberger, A. (2014). Diagnóstico de condutas e hábitos de saúde de estudantes universitários. Paradigma, 35(1), 167179. Retrieved from https://pdfs.semanticscholar.org/a23f/8eb1583626bo6e6123247fc30oe22ebe5b3f.pdf 
Chaves, J. C. (2016). Práticas afetivo-sexuais juvenis: Entre a superficialidade e o aprofundamento amoroso. Psicologia \& Sociedade, 28(2), 320-330. doi:10.1590/180703 102016 v28n2p320

Fennel, J. L. (2011). Men bring condoms, women take pills men's and women's roles in contraceptive decision making. Gender \& Society, 25(4), 496-521. doi:10.1177/ 0891243211416113

Gomes, A., \& Nunes, C. (2015). Análise comparativa entre clusters de uso de preservativo e comportamento de risco em estudantes universitários portugueses. Saúde e Sociedade São Paulo, 24(1), 350-360. doi:10.1590/S0104-12902015000100027

Heilborn, M. L., \& Cabral, C. D. S. (2013). Youth, gender and sexual practices in Brazil. Psicologia \& Sociedade, 25(n. esp.), 33-43. doi:10.1590/S0102-71822013000500005

Hugo, T. D. O., Maier, V. T., Jansen, K., Rodrigues, C. E. G., Cruzeiro, A. L. S., Ores, L. C., Pinheiro, R. T., Silva, R., \& Souza, L. D. M. (2011). Fatores associados à idade da primeira relação sexual em jovens: Estudo de base populacional. Cadernos de Saúde Pública, 27(11), 2207-2214. doi:10.1590/S0102-311X2011001100014

James-Hawkins, L., Dalessandro, C., \& Sennot, C. (2019). Conflicting contraceptive norms for men: Equal responsibility versus women's bodily autonomy. Culture, Health \& Sexuality, 21(3), 263-277. doi:10.1080/13691058.2018.1464209

Janeiro, J. M. S. V., Oliveira, I. M. S., Rodrigues, M. H. G., Maceiras, M. J., \& Rocha, G. M. M. (2013). As atitudes sexuais, contraceptivas, o lócus de controle da saúde e a autoestima em estudantes do ensino superior. Revista Brasileira em Promoção da Saúde, 26(4), 505-512. doi:10.5020/18061230.2013.p505

Magnusson, B. M., Crandall, A., \& Evans, K. (2019). Early sexual debut and risky sex in young adults: The role of low self-control. BMC Public Health, 19, 1-8. doi:10.1186/ s12889-019-7734-9

Ministério da Saúde. (2017). Boletim epidemiológico HIV/Aids. Brasília: Ministério da Saúde, Departamento de Vigilância, Prevenção e Controle das Infecções Sexualmente Transmissíveis, do HIV/Aids e das Hepatites Virais (DIAHV). Retrieved from http:// www.aids.gov.br/pt-br/pub/2017/boletim-epidemiologico-hivaids-2017

Monteiro, S., Tavares, J., \& Pereira, A. (2009). Adultez emergente: Na fronteira entre a adolescência e a adultez. Revista @mbienteeducação, 2(1), 129-137. Retrieved from http://publicacoes.unicid.edu.br/index.php/ambienteeducacao/article/view/545/512

Moreira, L. R., Dumith, S. C., \& Paludo, S. S. (2018). Uso de preservativos na última relação sexual entre universitários: Quantos usam e quem são? Ciência \& Saúde Coletiva, 23(4), 1255-1266. doi:10.1590/1413-81232018234.16492016 
Quintana, J. B., Calatayud, F. M., \& Lanterna, L. P. (2016). Aspectos psicosociales de la salud sexual y reproductiva en estudiantes universitarios. Salud \& Sociedad, 7(2), 180--195. doi:10.22199/S07187475.2016.0002.00004

Rich, A., Mullan, B. A., Sainsbury, K., \& Kuczmierczyk, A. R. (2014). The role of gender and sexual experience in predicting adolescent condom use intentions using the theory of planned behaviour. The European Journal of Contraception and Reproductive Health Care, 19, 295-305. doi:10.3109/13625187.2014.917624

Santos, N. S., Seidl-de-Moura, M. L., Victor, T. A. S., \& Ramos, D. O. (2016). Trajetórias de desenvolvimento e marcos de vida em jovens do Rio de Janeiro. Psicologia Clínica, 28(3), 135-152. Retrieved from pepsic.bvsalud.org/pdf/pc/v28n3/o8.pdf

Silva, L. P., Camargo, F. C., \& Iwamoto, H. H. (2014). Comportamento sexual dos acadêmicos ingressantes em cursos da área da saúde de uma universidade pública. Revista de Enfermagem e Atenção à Saúde, 3(1), 39-52. Retrieved from http://seer. uftm.edu.br/revistaeletronica/index.php/enfer/article/view/929/661

\section{Authors notes}

André T. Stephanou, Institute of Psychology, Psychology Graduate Program (PPG-PSICO), Federal University of Rio Grande do Sul (UFRGS); Marina Z. Delatorre, Institute of Psychology, Psychology Graduate Program (PPG-PSICO), Federal University of Rio Grande do Sul (UFRGS); Ana Cristina G. Dias, Institute of Psychology, Psychology Graduate Program (PPG-PSICO), Federal University of Rio Grande do Sul (UFRGS).

This study was financed in part by the Coordenação de Aperfeiçoamento de Pessoal de Nível Superior - Brasil (CAPES) - Finance Code 001, and by the Conselho Nacional de Desenvolvimento Científico e Tecnológico (CNPq) with Ph.D. and productivity grants (1D).

Correspondence concerning this article should be addresed to André Teixeira Stephanou, Instituto de Psicologia, sala 206, Rua Ramiro Barcelos, 2600, Santa Cecília, Porto Alegre, RS, Brasil. CEP 90035-003.

E-mail: astephanou@gmail.com 